Article

\title{
Are Unidentified Terrorist Suspects Always Muslims? How Terrorism News Shape News Consumers' Automatic Activation of Muslims as Perpetrators
}

\author{
Desirée Schmuck ${ }^{1}$, Jörg Matthes ${ }^{1, *}$, Christian von Sikorski ${ }^{1,2}$, Nicole Materne ${ }^{1}$ and \\ Ekata Shah ${ }^{1}$ \\ 1 Department of Communication, University of Vienna, Währinger Straße 29, 1090 Vienna, Austria; \\ desiree.schmuck@univie.ac.at (D.S.); christian.sikorski@univie.ac.at or vonsikorski@uni-landau.de (C.v.S.); \\ nicole-materne@gmx.de (N.M.); ekatashah101@gmail.com (E.S.) \\ 2 Department of Communication Psychology, University of Koblenz-Landau (Campus Landau), Fortstraße 7, \\ 76829 Landau, Germany; vonsikorski@uni-landau.de \\ * Correspondence: joerg.matthes@univie.ac.at; Tel.: +43-1-427749307
}

Received: 7 September 2018; Accepted: 17 September 2018; Published: 20 September 2018

\begin{abstract}
Two experimental studies investigated how news reports about terrorist attacks committed by unidentified perpetrators influence beliefs about the perpetrators and Muslims in general. In Study 1, a quota-based sample of 354 Germans was exposed to terror news coverage describing either non-Muslim or Muslim victims with no reference to the perpetrators of the attacks. Upon stimulus exposure, participants were asked the likelihood that the perpetrators were either Islamist extremists, far-right extremists, or lone operators. In Study 2, no information about the victims was provided, but the perpetrators were either Muslims or unidentified. In addition, we measured news consumers' Islamophobic attitudes in both studies. Results from Study 1 revealed that participants attributed perpetrator-unidentified attacks to Islamist perpetrators when the victims were non-Muslims. In contrast, terrorist attacks directed against Muslim victims were more likely to be attributed to far-right extremists. Additionally, Study 2 revealed that news consumers associated perpetrator-unidentified terrorist attacks with Islamist extremists to an equal degree as terrorist attacks that were committed by Muslim perpetrators. Attributing the attack to Islamists was in turn significantly related to Islamophobic attitudes in both studies. Implications of these findings for journalism practice and society at large are discussed.
\end{abstract}

Keywords: terrorism; news coverage; Islam; Muslim; Islamophobia

\section{Introduction}

Terrorist activities in Western societies are dominating the media landscape worldwide. The intensive media coverage about terrorist attacks committed by radical Islamist terrorists has raised concerns about unwanted and negative effects on intergroup relations between Muslims and non-Muslim majority members in Western societies. The news media's role in perpetuating stereotypes and prejudice is indisputable, as the media are one of the most important sources for many news consumers to learn about minority groups (Saleem and Anderson 2013; Saleem et al. 2016). More specifically, empirical research has repeatedly demonstrated that exposure to news reports that link terrorism to Islam may promote negative attitudes toward Muslims (e.g., Saleem et al. 2017; Von Sikorski et al. 2017, 2018).

Although the existing literature lacks a uniform definition of terrorism, terrorist acts have been defined by key criteria such as (a) the use of violence; (b) the intention to generate fear; and (c) the aim to influence citizens' political beliefs (Moghaddam and Marsella 2004; see also Nacos 2016). 
Terrorist attacks may be committed by a variety of different actors and organizations, including right-wing and left-wing political groups, nationalist groups, religious groups, revolutionaries, or lone operators (Global Terrorism Index 2017). In particular, news coverage of terrorist attacks committed by so-called radical Islamist terrorists has received vast research attention (e.g., Chuang and Roemer 2013; Ibrahim 2010; Mahony 2010; Hussain 2007; Powell 2011, 2018; Woods 2007). Islamism is described as a set of ideologies that are supposed to guide an individual's social as well as political life (Berman 2003). Extreme proponents of this ideology perceive political, economic, legal, and social aspects of other cultures to be incompatible with Islam (Eikmeier 2007). This form of Islamic fundamentalism and its demand for a strict adherence to particular religious views (Marsden 2006) may be clearly separated from moderate, respectively, modern forms of interpretation of Islam. Additionally, it is important to note that the term Islamism by itself refers "generally to a whole constellation of political movements and actors world-wide, only a tiny highly radical subset of which engage in acts of violence" (Piazza 2009, p. 64). Islamist terrorists claim to commit terrorist attacks in the name of Islam, which has stimulated controversial public discussions about the connection of Islam to terrorism in the past. The news media play a powerful role in shaping discussions about terrorism and Islam (Powell 2018). Although some studies show that the media avoid associating Muslims and Islamic organizations to terrorism (see Woods 2007), a wealth of research identifies a tendency to link Islam in general to terrorist threat (e.g., Ibrahim 2010; Powell 2011, 2018). In particular, after 9/11 and more recently in the context of the Islamic State (IS), Islam religion has been repeatedly associated with terrorism, extremism, or jihadism within the news (Ahmed and Matthes 2017; Mahony 2010; Satti 2015). As a consequence, non-Muslim news consumers may develop mental images of Muslim perpetrators as unfamiliar threatening characters, and non-Muslim terrorism victims as good, heroic familiar characters (Dixon 2007; see also Powell 2018). Those mental images may have detrimental effects on news consumers' attitudes toward Muslims, as prior research indicates that the cognitive association between social groups (e.g., Muslims) and social roles (e.g., terrorism) can be activated and reinforced through media consumption (Arendt 2015; Dixon 2007).

Yet, to date it remains completely unexplored how news reports about terrorist attacks that do not give any information about the perpetrators' identity (i.e., unidentified perpetrators) affect news consumers' perpetrator evaluations and attitudinal responses. Especially at an early stage of a terrorist attack, news reports often do not disclose any information about the perpetrator. However, priming research suggests that news consumers may nevertheless form beliefs about the perpetrator based on associations learned from prior news exposure (Devine 1989; Dixon 2007). As Muslims are highly overrepresented as perpetrators in terrorism news compared to other perpetrator groups, such as far-right fundamentalists (Dixon and Williams 2015), perpetrator-unidentified news reports may nevertheless contribute to negative attitudes toward Muslims as a social group. The underlying mechanism of that effect might be the automatic attribution of the attack to Islamist extremists. However, no research thus far has investigated the effects of perpetrator-unidentified news reports in the context of terrorism. Additionally, important influence factors, such as information about the victims, may shape those effects. More specifically, the content of terror news articles may direct news consumers' attention to specific aspects of the attack, such as characteristics of the victims, which should influence subsequent perceptions about the perpetrator. Accordingly, the aim of the present research was threefold: First, we investigated how perpetrator evaluations vary as a function of the victims' religious group (i.e., non-Muslims versus Muslims). Second, we examined how perpetrator evaluations differ in response to perpetrator-unidentified terrorist attacks and terrorist attacks committed by Muslim perpetrators. Third, we aimed to shed some light on the implications of perpetrator perceptions for Islamophobic attitudes. Especially, when terrorists are assumed to be Islamist fundamentalists, these assumptions might affect individuals' attitudes toward Muslims and Islam in general. 


\section{Automatic Activation of Perpetrator Perceptions}

Literature on priming and chronic activation suggests that categorizing individuals as part of stigmatized social groups leads to the activation of constructs that automatically link group members with various stereotypical traits (Dixon 2007; Higgins 2000; Eagly and Chaiken 1993; Livingston 2001). That recently activated information about a group subsequently influences judgment formation of group-related stimuli. This process is called priming (Higgins 2000). Regular exposure to media portrayals that emphasize positive attributes of the "good" in-group and negative attributes of the "bad" out-group may contribute to the development of stereotypical memory traces, which easily can be reactivated by subsequent exposure (e.g., Mendelberg 2001; Valentino et al. 2002). In the context of terrorism, numerous studies suggest that news media may perpetuate negative attitudes toward Muslims by frequently associating terrorism with Muslims or Islam (Saleem et al. 2016, 2017; Von Sikorski et al. 2017, 2018). However, less research has been devoted to the question how terrorism news that do not give any information about the perpetrator of an attack influence individuals' attitudes toward Muslims. Especially, at an early stage of a terrorist attack, news outlets often do not mention specific characteristics about the perpetrator (such as nationality, religion, or motives) due to the lack of confirmed information by official authorities. Powell $(2011,2018)$ investigated patterns of news coverage in the aftermath of a terrorist attack. She found that a terrorist event is labelled as "terrorism" in a first step. In a second step, information about the victims is given and in a third step, terrorists are labelled as Muslims or non-Muslims (see Powell 2018).

Yet, given the overrepresentation of perpetrators who self-identify as Muslims in the news (Dixon and Williams 2015), the mere exposure to terrorism news is likely to activate thoughts about a particular group of perpetrators that has frequently been portrayed in the news: Islamist terrorists (Price and Tewksbury 1997; Dixon 2007). That is, although a terrorist perpetrator remains unidentified, simple exposure to the construct of terrorism may enhance the automatic attribution of the attack to Islamist fundamentalists who self-identify as Muslims. In support of that assumption, a study by Dixon (2007) revealed that news viewers exposed to a race-unidentified suspect expressed a high likelihood that the perpetrator was African American. Additionally, heavy news viewers were more likely than light news viewers to misremember an unidentified perpetrator as a Black perpetrator (see also Dixon 2006). Extrapolating that finding to terrorism news, it might be assumed that exposure to terrorism news fosters the chronic activation of stereotypes linking minority groups to negative attributes, such as lawbreaking or terrorism. That is, when presented with unidentified terrorist suspects, news consumers might use multiple exemplars from prior news viewing to "fill-in-the blank" with stereotypical associations when making relevant judgments (Dixon 2007). Information about the victims in news reports may provide a heuristic for news consumers when making their judgment about the perpetrator. According to self-categorization theory (Turner et al. 1987), the way in which individuals perceive other people is rather flexible. News media portrayals may enhance the salience of certain identity aspects by highlighting some aspects and ignoring others (Major and O'Brien 2005). Following from that view, the content of terror news articles will direct viewers' attention to specific aspects of the victims of the attack, which should influence subsequent perceptions about the perpetrator.

We therefore suggested that non-Muslim news consumers exposed to perpetrator-unidentified terrorism news reports should be more likely to assume that the perpetrators were Islamists when the victims of the attack are non-Muslims rather than Muslims. Thus, our first hypothesis states:

Hypothesis 1 (H1). News consumers exposed to news reports about terrorist attacks are more likely to automatically attribute the attacks to Islamist perpetrators when the news reports mention non-Muslim victims rather than Muslim victims.

Numerous studies indicate that Muslims are often heavily misrepresented in the media by being associated with negative attributes, such as terrorism or extremism (Dixon and Williams 2015; 
Powell 2018). However, less research has been devoted to the portrayal of Muslims as victims of terrorist attacks. With a few exceptions, victims of terrorism are mainly portrayed as non-Muslims. However, the threat of terrorist attacks has also increasingly become salient for Muslim citizens in Western societies. The repeated association of terrorism with Islam has triggered an increase of revenge attacks against Muslims in the U.S. as well as in Europe (The Guardian 2017). The Quebec mosque shooting in 2017, which left six Muslims dead and injured 19 others, is one example for a terrorist attack that was purposefully directed against Muslims. Furthermore, one person was killed and several injured when a van drove into pedestrians at a mosque in London. Witnesses quoted the driver as shouting, "I want to kill all Muslims" (The Independent 2017). Those attacks are often linked to far-right extremists with nationalistic, anti-Muslim views. These so-called hate-crimes can be defined as "terrorism", as they are carried out in order to deliver a political message to a target population and to create fear or terror (Powell 2018). Although news viewers are exposed to such attacks less frequently, they may nevertheless have developed cognitive associations between terrorist attacks directed against Muslims and far-right extremists. Thus, perpetrator-unidentified terrorism attacks with Muslim victims may therefore be automatically attributed to perpetrators with a far-right ideology. Hence, we hypothesized:

Hypothesis 2 (H2). News consumers exposed to news reports about terrorist attacks are more likely to automatically attribute the attacks to far-right extremist perpetrators when the news reports mention Muslim victims rather than non-Muslim victims.

\section{Terrorism News and Islamophobic Attitudes}

Terrorism news may not only stimulate perpetrator evaluations; they may also affect news consumers' attitudes toward social groups. The repetitive reporting about terrorists who connect their ideology to Islamic beliefs-thus misusing the Islamic religion for their inhuman aims-may seriously affect news consumers' attitudes toward Muslims in general. Besides rising levels of anxiety and uncertainty in non-Muslim citizens in general, terrorism news may increase Islamophobia and negative stereotypes toward (well-integrated) Muslim out-group members. There is first research evidence suggesting that news reports prime the association of offensive attributes, such as aggressiveness and terrorist tendencies, with Muslims in general (Saleem et al. 2017). Moreover, previous work has suggested that negative stereotypes in response to news about Islamist terrorism are transferred from a few Islamist extremists to Muslims in general (Von Sikorski et al. 2018). That effect can be explained by a stereotype-generalization account postulating that news about Islamist terrorist threats are likely to increase negative attitudes of Muslims in general because negative associations with one exemplar (i.e., an Islamist terrorist) become generalized to all individuals considered to belong to the same sociocultural group (Das et al. 2009). In-group individuals tend to perceive out-group members to be more homogeneous than in-group members; this is a phenomenon called the out-group homogeneity effect (Park and Rothbart 1982; Rothgerber 1997). Based on the idea of the out-group homogeneity effect, it can be suggested that ingroup individuals-for example, non-Muslims in Western societies-perceive out-group members-Muslims in those societies-as less variable than in-group members and more similar to one another (Von Sikorski et al. 2018). Thus, for non-Muslim news consumers, the categories of Islamist extremists and Muslims in general may overlap and they may perceive all Muslims, including terrorists who misuse the Islamic religion, to be similar (Hogg and Reid 2006). Therefore, we expected that news consumers who attribute terrorist attacks to Islamist perpetrators may transfer the negative attributes associated with those perpetrators to Muslims in general. As a consequence, they may hold more negative attitudes toward Muslims as a whole. In line with that assumption, we expected that: 
Hypothesis 3 (H3). The automatic attribution of terrorist attacks to Islamist perpetrators will increase Islamophobic attitudes.

In contrast, the automatic attribution of terrorist attacks to far-right extremists might even decrease Islamophobic attitudes due to compassion or empathy with the Muslim victims. However, as no research thus far has investigated how the attribution of terrorist attacks to far-right extremists is associated with Islamophobic attitudes, we pose a research question asking:

Research Question (RQ). How is the automatic attribution of terrorist attacks to far-right extremist perpetrators related to Islamophobic attitudes?

The full theoretical model including all hypotheses and the research question is depicted in Figure 1.

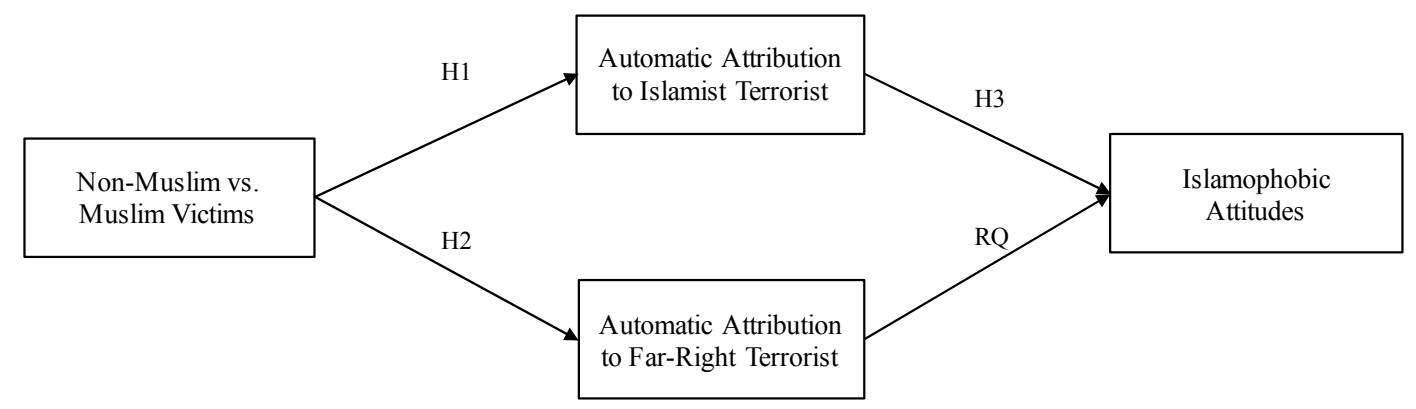

Figure 1. Hypothesized Theoretical Model.

\section{Study 1}

\subsection{Method}

In Study 1, we used a quota sample based on the demographic characteristics of the general population in Germany. The experiment was part of a larger online survey conducted by Survey Sampling International (SSI) in July 2017 to August 2017. In total, 380 participants were randomly assigned to the current study. In total, 24 participants with very low (below $5 \mathrm{~min}$ ) or very high (above $60 \mathrm{~min}$ ) response times were excluded. Additionally, respondents with Islam religious denomination $(N=2)$ were excluded, which resulted in a final sample of 354 participants ( $53 \%$ female; $M_{\text {age }}=48.20$, $S D=15.42$; ranging from 16 to 69 years old; $2.9 \%$ no school degree, $29.7 \%$ compulsory school; $34.7 \%$ vocational school degree, $18 \%$ with a high school degree; $14.7 \%$ with an academic degree).

\subsubsection{Experimental Procedure}

We employed a between-subjects design by systematically varying the victims' religious group (Muslim versus non-Muslim). We randomly assigned participants to the two experimental groups: news about terrorist attacks with non-Muslim victims $(n=175)$ and news about terrorist attacks with Muslim victims $(n=179)$. A second experimental factor was removed from the design due to insignificant effects and irrelevance for the research interest of the current study. After giving their informed consent to participate, participants were exposed to two different news articles about terrorism. Participants had to spend at least $20 \mathrm{~s}$ reading each news article before they could continue to the next article. This procedure prevented participants from clicking through the survey without reading the articles. Upon stimulus exposure, participants responded to a computer-administered survey, which first included the assumed mediators followed by the dependent variable. After completion, we thanked and debriefed participants. A randomization check revealed no significant effects of experimental condition on gender, age, education, immigration background, political predisposition, religious denomination, frequency of contact with Muslims, and perceived quality of contact with Muslims, indicating that randomization was successful. 


\subsubsection{Stimulus Material}

We exposed participants in all experimental groups to two news articles about different terrorist events (see Appendix A). We used the original layout of two German online news outlets: Focus.de and Welt.de. The first article portrayed a knife attack at a street festival in a small German town (Halle an der Saale), mentioning that seven people were heavily injured. The article either emphasized that all victims were Muslims or non-Muslims. The second news article described a shooting in Berlin (Germany). In the version with Muslim victims, the attack took place in front of a mosque and left five Muslims injured. In an otherwise identical version with non-Muslim victims, the shooting occurred in front of a church and no Muslim victims were mentioned. Both articles labelled the attacks as "terrorist attacks" and provided no details on the terrorists' motives or identities. That is, we only varied the victims' religion, while the perpetrators' identity (unidentified) was held constant across all experimental conditions.

\subsubsection{Pretest of Stimulus Material}

We conducted a pretest among a student sample $\left(N=43,74 \%\right.$ female, $\left.M_{\text {age }}=26.28, S D=9.03\right)$. Participants could correctly indicate whether the victims were Muslims, $F(1,41)=210.80, p<0.001$, $\eta^{2}=0.84$, or non-Muslims, $F(1,41)=265.94, p<0.001, \eta^{2}=0.87$. Finally, the news articles' perceived credibility did not differ significantly across the experimental conditions, $F(1,41)=0.65, p=0.42$, $\eta^{2}=0.02$.

\subsubsection{Manipulation Check}

We examined the effectiveness of our religious group salience manipulation by asking participants about the portrayed victims' religion. Participants indicated to a higher degree that the terrorist act targeted Muslims under the Muslim victim conditions compared to the non-Muslim victim conditions, $F(1,352)=313.54, p<0.001, \eta^{2}=0.47$, and that the terrorist act targeted non-Muslims under the non-Muslim compared to the Muslim victim conditions, $F(1,352)=179.34, p<0.001, \eta^{2}=0.34$. Thus, the results revealed a successful manipulation.

\subsubsection{Measures}

To assess perpetrator perceptions, we asked participants who they thought was responsible for the terrorist attacks. Participants could indicate whether they perceived the terrorists as (1) Islamist extremists (e.g., members of the Islamic state); (2) far-right radical extremists (e.g., so-called "Reichsbürger"); (3) lone operators, which do not belong to any organization; or (4) others. To assess Islamophobic attitudes, we developed five items based on scales by Lee et al. (2009) and Park et al. (2007) ("The religion of Islam supports acts of violence; Islam is a religion of hate; I believe that Muslims support the killings of all non-Muslims; Too many Muslims harm Germany; The share of Muslims in Germany is too high; 7-point Likert scale; Cronbach's $\alpha=0.95, M=4.13, S D=1.94$ ).

\subsubsection{Data Analysis}

We used the software $R$. We computed a dummy variable for the independent variable victim religion (with Muslim religion as reference category). For perpetrator perceptions, we created two dummy variables, one for perceptions of the perpetrator as an Islamist extremist and one for perceptions of the perpetrator as a far-right extremist. Perceptions of the terrorist as a lone operator or another terrorist not belonging to an organization served as reference category. These two dummy variables were modelled as mediators of the effects of terror news coverage exposure on the dependent variable Islamophobic attitudes. To test the effects of the independent variable on the mediators we used logistic regression analyses as the mediators are dichotomous. To assess the effects of the independent variable and the mediators on Islamophobia, linear regression analyses were computed. To assess the indirect effects of the independent variable on the dependent variable via the mediators, 
we used the mediation package in $R$ with 10,000 simulations for statistical inference of indirect effects (Imai et al. 2010; Tingley et al. 2014).

\subsection{Results}

\subsubsection{Descriptives}

Overall, the majority of participants assumed that the perpetrators were Islamist extremists ( $42.9 \%)$; followed by lone operators, which do not belong to any extremist group (40.1\%); far-right extremists (14.7\%); and other terrorists not belonging to any of those three groups (2.3\%).

\subsubsection{Multivariate Analyses}

All findings are portrayed in Figure 2. In order to test our first hypothesis, we conducted a binomial logistic regression analysis. Our results revealed that non-Muslim news consumers were more likely to indicate that the unidentified perpetrators were Islamist perpetrators rather than lone operators not belonging to any organization when the victims in the news articles were described as non-Muslims compared to Muslims $(b=1.24$, standard error (SE) $=0.23, p<0.001)$. This finding supports our first hypothesis (H1). However, news reports about terrorist attacks directed against non-Muslim victims were significantly less likely to be attributed to far-right extreme perpetrators than to lone operators compared to news reports describing Muslim victims $(b=-2.30, \mathrm{SE}=0.45$, $p<0.001)$. Put differently, attacks directed against Muslim victims rather than non-Muslim victims were more likely to be ascribed to far-right extremists, which confirms our second hypothesis (H2).

Furthermore, we tested whether perpetrator attributions would be related to Islamophobic attitudes. In support of our third hypothesis (H3), we found that perceiving the perpetrators as Islamists rather than as lone operators was significantly and positively related to Islamophobic attitudes $(b=0.56, S E=0.23, p=0.014)$. In contrast, perceiving the perpetrators as far-right extremists rather than as lone operators was not related to Islamophobic attitudes $(b=0.31, \mathrm{SE}=0.32, p=0.331$ ), which answers our research question (RQ). There was no direct effect of news exposure on Islamophobic attitudes $(b=-0.04, \mathrm{SE}=0.22, p=0.860)$.

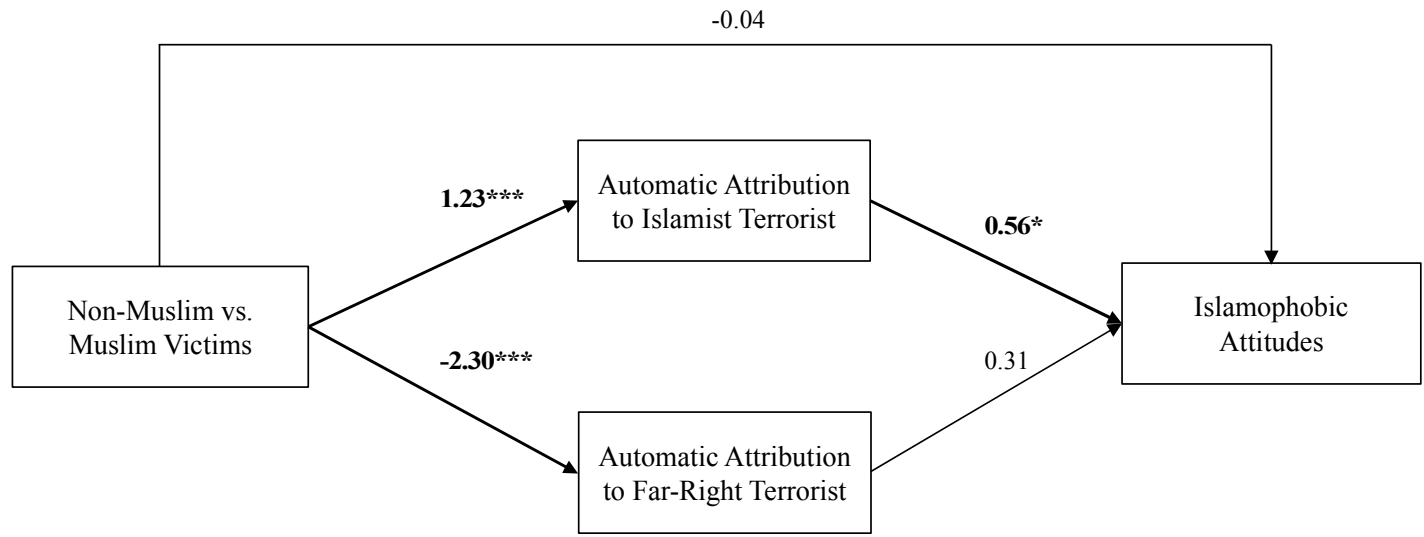

Figure 2. Unstandardized path coefficients. Bold lines indicate significant effects. ${ }^{*} p<0.05 ;{ }^{* * *} p<0.001$.

To investigate the indirect effect of exposure to the news articles on Islamophobic attitudes, we estimated the indirect effect using quasi-Bayesian Monte Carlo simulation with 10,000 simulations. As we are using a binary mediator, the coefficients represent the increase in probability for attributing the attack to Islamists or far-right perpetrators (Tingley et al. 2014). Results revealed a significant indirect effect of exposure to news articles describing the victims as non-Muslims rather than Muslims on Islamophobic attitudes via the automatic attribution of the attack to Islamist perpetrators (95\% CIs [0.03; 0.33]). However, we found no significant indirect effect of news article exposure on Islamophobia via the perception of the perpetrators as far-right extremists ( $95 \%$ CIs [ $-0.23 ; 0.07])$. 


\subsection{Discussion Study 1}

In Study 1, we aimed to investigate whether varying the victims' religious identity in news articles about terrorism would have an impact on perpetrator evaluations. In doing so, we placed our focus on the victims of terrorism and systematically varied the victims' religious group (Muslims versus non-Muslims). The perpetrators were held constant across all experimental conditions by providing no details on the terrorists' motives or identities in the news articles. In line with priming theory, we found that unidentified terrorists are more likely to be perceived as Islamist extremists when the victims of the attacks are non-Muslims. Thus, due to associations learned by multiple exposure to social categories, such as Muslim perpetrators and non-Muslim victims, news consumers seem to "fill in the blanks" when no perpetrator is mentioned (Dixon 2007). Additionally, we found that attributing the attacks to Islamist perpetrators may enhance Islamophobic attitudes among non-Muslim news consumers. When the attack is directed against Muslim victims, however, news consumers are more likely to ascribe the attack to far-right extremists. There are several explanations for that finding. On the one hand, news consumers may base their perpetrator evaluations on information learned by prior news exposure. As attacks against Muslims have often been conducted by far-right extremists in the past, individuals might have used that information when given the opportunity to evaluate the perpetrator (Dixon 2007). Hence, when confronted with a difficult judgment (i.e., evaluating an unidentified perpetrator), individuals relied on cognitive heuristics; that is, they relied on those constructs that seemed most familiar (Dixon 2007). On the other hand, categories of Islamist extremists and Muslims in general may overlap for non-Muslim news consumers. Therefore, the probability of an attack directed against members of the same group might have seemed unlikely, which is why the attacks were attributed to far-right extremists rather than to Islamists.

Furthermore, we found that attributing the attacks to far-right perpetrators was not associated with Islamophobic attitudes. Thus, only when individuals perceived the terrorists as Islamists did they react with more hostile attitudes toward Muslims in general. This effect can be explained by the out-group homogeneity effect, which facilitates attitude transfer between group members of the out-group (Ranganath and Nosek 2008). Thus, negative attributes associated with one exemplar (i.e., Islamist extremists) may be transferred between potentially overlapping out-group categories. Therefore, negative perpetrator perceptions associated with Islamists (i.e., potential overlap) but not with far-right extremists (i.e., no overlap) were transferred to Muslims in general. Potential implications of that finding will be discussed below.

Finally, an important limitation of this study needs to be mentioned. The main goal of Study 1 was to investigate how perpetrator perceptions are formed as a function of the victim's religious group. Yet, by providing information about the victims, the news reports might have automatically stimulated suggestions about the perpetrators as well. In other words, although we did not provide any information about the perpetrators of the attacks, mentioning the victims' religious group might have served as a cue for the perpetrators of the attack. Therefore, we conducted a second study using a condition without any cues about the victims' or perpetrators' identity.

\section{Study 2}

Study 2 was designed to investigate more thoroughly whether perpetrator-unidentified terrorist attacks are associated with Islamist terrorism in the absence of any cues to the victims' identity (i.e., without mentioning the victims' religious group). Specifically, we examined whether perpetrator-unidentified terrorist attacks are equally associated with Islamist terrorism as terrorist attacks committed by Muslim perpetrators. Based on the findings of Study 1 suggesting that perpetrator-unidentified news articles are automatically attributed to Islamist extremists, we expected no difference with regard to perpetrator perceptions in response to news articles mentioning Muslim perpetrators or unidentified perpetrators. Put differently, terrorist attacks not providing any information about the perpetrators should be as likely to be attributed to Islamist extremists as news articles explicitly mentioning Muslim perpetrators. Therefore, we proposed: 
Hypothesis 4 (H4). News consumers exposed to news reports about terrorist attacks are equally likely to automatically attribute the attacks to Islamist perpetrators when the news reports mention Muslim perpetrators or unidentified perpetrators.

Furthermore, in an attempt to replicate our findings from Study 1, we tested whether news consumers who attribute terrorist attacks to Islamist perpetrators transfer the negative attributes associated with those perpetrators to Muslims in general. Thus, we hypothesized:

Hypothesis 5 (H5). The automatic attribution of terrorist attacks to Islamist perpetrators will increase Islamophobic attitudes.

\subsection{Method}

The experiment was conducted from October 2017 to November 2017. In total, 77 participants participated in the current study. The experiment was part of a larger study unrelated to the purposes of the present paper. We used a convenience sample in Germany ( $74 \%$ female; $M_{\text {age }}=26.51, S D=7.62$; ranging from 19 to 60 years old; $1.3 \%$ compulsory school; $23.4 \%$ with a high school degree; $75.3 \%$ with an academic degree). None of the participants had an Islamic religious denomination.

\subsubsection{Experimental Procedure}

We employed a between-subjects design by systematically varying the perpetrators' religious group (Muslim versus no religion). We randomly assigned participants to the two experimental groups: news about terrorist attacks committed by Muslim perpetrators $(n=37)$ and news about terrorist attacks committed by unidentified perpetrators $(n=40)$. After giving their informed consent, participants were exposed to two different news articles about terrorism. Upon stimulus exposure, participants responded to a computer-administered survey, which first included the assumed mediators followed by the dependent variable. After completion, we thanked and debriefed participants. A randomization check revealed no significant effects of experimental condition on gender, age, education, immigration background, political predisposition, religious denomination, frequency of contact with Muslims, and perceived quality of contact with Muslims, indicating that randomization was successful.

\subsubsection{Stimulus Material}

We exposed participants in both experimental groups to two news articles about different terrorist events (see Appendix B). The news articles resembled original news articles published in German news outlets. The first article portrayed a shooting in a popular gay bar in Berlin (Germany), mentioning that two people were killed and eleven heavily injured. The article did not give any information about the victims' identity or religious group. In the version with the Muslim perpetrator, the article mentioned that the perpetrator was wearing a Qur'an in his bag and had a necklace with an Islamic symbol. In an otherwise identical version, the article stated that no information about the perpetrator was yet confirmed. The second news article described a knife attack in Karlsruhe (Germany) during a demonstration for women's rights, which left five people injured. In the version with the Muslim perpetrator, the article mentioned that the perpetrator was described as a devoted Muslim wearing a Taqijah (a religious skullcap) and screamed during his arrest "I did this for Allah". In an otherwise identical version, the article stated that the police had not yet revealed any information about the perpetrator. That is, we only varied the perpetrator's identity, while all remaining information was held constant across all experimental conditions.

\subsubsection{Manipulation Check}

We examined the effectiveness of our perpetrator manipulation by asking participants whether the perpetrator's religion was mentioned in the news articles. Participants could correctly indicate that 
the perpetrator's religion was mentioned in the first news article, $X^{2}(1)=41.95, p<0.001$, as well as in the second news article, $X^{2}(1)=54.57, p<0.001$. Specifically, $90 \%$ of the participants correctly indicated that no religion was mentioned in the perpetrator-unidentified article, and $100 \%$ of the participants could correctly recall that the perpetrator's religion was mentioned in the Muslim condition. For the second news article, $90.6 \%$ of the participants under the perpetrator-unidentified condition could correctly indicate that the perpetrator's religion was not mentioned, while $88.6 \%$ of the participants correctly indicated that the perpetrator's religion was mentioned under the Muslim condition.

\subsubsection{Measures}

To assess perpetrator perceptions, we asked participants who they thought was responsible for the terrorist attacks. On a 7-point Likert scale, participants could indicate how likely (ranging from $1=$ highly unlikely to $7=$ highly likely) they thought it was that the attack was committed by Islamist extremists. To assess Islamophobic attitudes, we used the same items as in Study 1 (Cronbach's $\alpha=0.94$, $M=2.92, S D=1.82$ ).

\subsubsection{Data Analysis}

For data analysis, we used the software $R$. We computed a dummy variable for the independent variable perpetrator religion (with unidentified perpetrator as a reference category). We used the perceived likelihood that the perpetrators were Islamist extremists as a mediator of the effects of terror news coverage exposure on the dependent variable Islamophobic attitudes. To assess the effects of the independent variable on the mediators and Islamophobia, linear regression analyses were computed. As in Study 1, we used the mediation package in $R$ with 10,000 simulations for statistical inference of indirect effects.

\subsection{Results}

Our results revealed that non-Muslim news consumers were not significantly more likely to indicate that the perpetrators were Islamist extremists when the perpetrators were described as Muslims compared to when the perpetrators were unidentified ( $b=0.54, \mathrm{SE}=0.38, p=0.157$ ). This finding suggests that perpetrator-unidentified terrorist attacks are equally likely to be attributed to Islamist extremists as attacks committed by Muslim perpetrators, which confirms $\mathrm{H} 4$.

Furthermore, as in Study 1, we tested whether perpetrator attributions would be related to Islamophobic attitudes. We found that perceiving the perpetrators as Islamists was significantly and positively related to Islamophobic attitudes $(\mathrm{b}=0.28, \mathrm{SE}=0.13, p=0.036)$. Thus, $\mathrm{H} 5$ could be supported. There was no direct effect of news exposure on Islamophobic attitudes $(b=0.06, \mathrm{SE}=0.42, p=0.889)$. Additionally, results revealed no significant indirect effect of news exposure on Islamophobic attitudes via the attribution of the attack to Islamist perpetrators (95\% CIs [-0.06; 0.47]).

\subsection{Discussion Study 2}

Overall, the findings of Study 2 provided additional evidence for the assumption that perpetrator-unidentified terrorist attacks are automatically attributed to Islamist perpetrators. Specifically, the findings showed that perpetrator-unidentified terrorist attacks are equally attributed to Islamist perpetrators as terrorist attacks committed by Muslim perpetrators. Thus, in the absence of any cues to the perpetrators' identity (i.e., without mentioning the victims' religious group), perpetrator-unidentified attacks are nevertheless attributed to Islamist perpetrators. In fact, news consumers perceived the probability that the perpetrator-unidentified attacks were committed by Islamist extremists as equally high as when the perpetrators were clearly disclosed as Muslims. This effect occurred although individuals could correctly recall that the perpetrators' religious affiliation was not mentioned in the news articles. Those findings suggest that even when no cues about the victims' identity are given, news consumers will nevertheless associate a perpetrator-unidentified attack with Islamist extremists (Dixon 2007). That association, in turn, fosters Islamophobic attitudes. 
As in Study 1, we found that perceiving the perpetrators as Islamist extremists increased Islamophobic attitudes in turn. Hence, individuals generalized their negative associations with the terrorists to the out-group of Muslims as a whole (Ranganath and Nosek 2008). However, some important limitations of this study need to be taken into account. As we used a convenience sample, female and higher-educated participants were overrepresented in this study. Additionally, we used a single item to measure perpetrator perceptions in response to news exposure. Therefore, future studies employing a representative sample as well as more differentiated measures are needed to bolster these findings.

\section{General Discussion}

Using two experimental studies, we investigated for the first time how terrorism news reports not mentioning characteristics about the perpetrators-as it is frequently the case at the early stage of news coverage about a terrorist event-influence news consumers' evaluations of the perpetrators and attitudes toward Muslims in general. In line with priming theory, we found that news consumers attribute perpetrator-unidentified terrorist attacks to Islamist extremists both in the absence and presence of cues about the victims. Thus, news consumers seem to "fill in the blanks" based on associations learned from repeated exposure to the association of terrorism with Islam (Dixon 2007). Therefore, when given an opportunity to evaluate unidentified terrorist perpetrators, news consumers are more likely to associate those perpetrators with Islam and assume that they are Islamist extremists.

It is well-documented that terrorism news consistently overrepresent Muslims as terrorism perpetrators. In the U.S. context, Dixon and Williams (2015) revealed that Muslims are much more likely to be portrayed as terrorists than to actually be terrorists in U.S. society according to official reports, while non-Muslims are underrepresented compared to how often they appear as terrorists in society. That misrepresentation seems to lead to the chronic activation of the linkage between Islam and terrorism. Thus, when news consumers read news reports about a terrorist attack, they are more likely to automatically attribute the attack to Islamist perpetrators irrespective of whether there is confirmed information about a linkage of the attack to Islam or not. Specifically, we found that when the victims of the terrorist attacks are described as non-Muslims, news consumers suggest that the perpetrators are Islamists. However, we also found that when no cues about the victims are provided in the news reports, news consumers nevertheless assume that the perpetrators were Islamist extremists. Even more importantly, the estimated likelihood of the perpetrators being Islamists did not differ in response to perpetrator-unidentified news articles and news articles actually describing the perpetrators as having an Islamic religious affiliation. The tendency to associate the attacks with Islamist perpetrators was only decreased when the victims were explicitly described as Muslims. In this case, news consumers assumed the perpetrators to be far-right extremists. Hence, news consumers connect what they read and see with information learned by prior news exposure (Dixon 2007). Most importantly, explicitly stating that no information about the perpetrators is yet confirmed does not seem to prevent that automatic attribution.

However, attributing a terrorist attack to Islamist perpetrators has important implications for attitudes toward Muslims in general. In line with previous research, both our studies revealed that the automatic attribution of the attacks to Islamist perpetrators promoted hostile attitudes toward Muslims in general. Stereotype generalization may explain that effect. Attitudes are transferred more readily between group members of the out-group compared to group members of the in-group (Ranganath and Nosek 2008). Accordingly, negative attributes associated with Islamist terrorists may be transferred between potentially overlapping out-group categories. If Muslims as well as Islamic fundamentalists are both perceived to belong to the out-group "Muslims", news consumers will transfer negative evaluations of Islamic fundamentalists to Muslims in general. In particular, when the out-group is evaluated negatively, perceived out-group homogeneity makes it easier to take action because there is no need to distinguish between out-group members ("They have all harmed us") (Rothgerber 1997, p. 1207). Thus, in sum, it can be concluded that perceiving terrorist perpetrators as Islamists may increase Islamophobic attitudes toward Muslims in general due to a negative 
generalization effect of negative attributes, which biases subsequent attitude formation. In contrast, associating the perpetrators with a far-right ideology did not affect Islamophobic attitudes. Hence, Islamophobic attitudes were only increased when the perpetrators were associated with an Islamist ideology, which underlines the assumption that in line with the out-group homogeneity effect, Islamist perpetrators and Muslims were categorized in overlapping out-group categories.

\subsection{Limitations and Future Research}

This research has some important limitations. First, although we used an experimental approach to establish a causal relationship between news exposure and Islamophobic attitudes, all dependent variables were measured at one point of time, which strictly speaking only allows correlational evidence for perpetrator perceptions and Islamophobic attitudes. Second, this is the first study to investigate how perpetrator-unidentified terrorism news articles affect news consumers' attitudinal responses. Of course, future research is needed to bolster those results and to include additional factors, such as other characteristics about the victims, the type of terrorist attack, and perpetrator motives, that may influence news consumers' perpetrator evaluations. Third, this study has not investigated further implications of Islamophobic attitudes. Future studies should consider additional dependent variables, such as support for punitive measures, support for victim compensation, anti-Muslim policies, or immigration policies. Lastly, our design did not include Muslim respondents. Forthcoming studies should extend this design and test whether the findings presented here may also be transferred to Muslim news consumers.

\subsection{Implications}

Despite those limitations, our study has important implications for journalism practice and society at large. First, unless the victims are Muslims, our findings suggest that news consumers exposed to unidentified terrorists will associate what they read and see with Islam. Journalists should be highly aware of that tendency and employ strategies to counteract those unintentional effects, for instance, by putting an even stronger emphasis on base-rate information. Additionally, making Muslims as victims of terrorism visible in news coverage seems to be an important task for journalists. Muslims are overrepresented as perpetrators of terrorist attacks, but underrepresented as victims. Yet, terrorism is a salient threat for both Muslims and non-Muslims around the world. Therefore, diverse role portrayals may be the key to counteracting negative effects of terrorism news over time. Overall, the most fruitful strategy would be preventing the chronic activation of the linkage between Islam and terrorism in the first place. Journalists should, on the one hand, critically reflect on the intensity with which they report different types of terrorism to avoid an overrepresentation of Islamist terrorism and an underrepresentation of home-grown terrorism in the news overall. Additionally, if terrorist attacks are indeed committed by Islamist extremists, journalists should actively engage in news differentiation by explicitly distinguishing between more general and open-ended sets (e.g., Muslims in general) and the characteristics and activities of individual people (e.g., Islamist terrorists). This so-called news differentiation has been found to prevent the formation of Islamophobic attitudes in response to terrorism news (Von Sikorski et al. 2017, 2018). Finally, our study points to the necessity in politics and society to provide continued opportunities for non-Muslims to interact in positive and meaningful ways with Muslims to counteract automatic stereotype activation in the long-term. For instance, community-based activities, sports programs, or school-based activities involving both Muslim and non-Muslim citizens in Western societies (see e.g., Wise and Ali 2008) may help decrease mutual prejudice.

Author Contributions: Conceptualization, D.S., J.M., C.v.S.; Formal analysis, D.S.; Funding acquisition, J.M.; Investigation, D.S., N.M., E.S.; Methodology, D.S., J.M., C.v.S., N.M., E.S.; Project administration, D.S., N.M., E.S.; Supervision, J.M.; Writing—original draft, D.S., Writing—review \& editing, D.S., J.M., C.v.S.

Funding: This research received no external funding. 
Conflicts of Interest: The authors declare no conflict of interest.

\section{Appendix A. Stimulus Material Study 1}

\section{Appendix A.1. News Article 1}

[Muslim version/non-Muslim version] Five people injured in a shooting in front of a [mosque/church] in Berlin. The attacker targeted [Muslims/"disbelievers"]. A security camera reveals how the perpetrator approaches a victim and shoots him in the leg.

Berlin-Five people were injured in a shooting in front of a [mosque/church] in the neighborhood of Neuköln, Berlin. The prosecution assumes a terrorist act. According to first eyewitness reports, the shooting was conducted by a man using a hunting gun. The shooter appeared in front of the [Şehitlik mosque/Martin Luther church] at around 22:30 p.m. Then he started shooting people who were leaving the [mosque/church], according to the investigators. According to eyewitnesses, people got in panic when the shooting started. In total, five people were injured, a police spokeswoman said. All victims are members of the [Muslim religious community/Christian religious community as well as non-Muslim passersby]. The police assume that the man was acting alone. The alleged perpetrator, who could be arrested by the police shortly after the incident, was described as "male and between 20 and 30 years old". Recordings by a security camera show how one of the victims, Yasser K. (61 years) was shot in the leg. "He looks very scared in the video. He could see the man coming toward him. He had no chance to escape or defend himself. The perpetrator pointed a gun at him-seemingly without a reason. Then a shot was heard and the man was hit", a police spokeswoman comments on the recordings.

\section{Appendix A.2. News Article 2}

[Muslim version/non-Muslim version] Knife attack at street festival in Halle. Seven people injured-mayor speaks of terror targeted against [Muslims/people who do not belong to the Muslim community].

Halle (Saale) — Seven people were injured on yesterday's Wednesday afternoon in a knife attack at the margins of a street festival in Halle an der Saale. Anti-terror investigations are ongoing. The incident at the street music festival "Festival of Diversity" in Halle, where traditionally people with different religions celebrate together, was an attack targeted at people with [Muslim faith/non-Muslim faith]. According to eyewitnesses, a man willingly attacked a group of [Muslims/people] at the margins of the street festival. He intentionally targeted this group of [Muslims/people] and stabbed them. He cried "this is my contribution, [Muslims/disbelievers] have to die", an eyewitness said on Monday to the ZDF. Visitors of the festival could finally stop the man and hand him over to the police. All victims were brought in the nearby hospital St. Marien, police spokesman Georg Kleinmann confirms. A neighbor observed an attack on a young woman, who was injured at her arms and legs. "I saw a young woman who tried to protect her daughter. She seemed very scared and helpless. He stabbed her without warning, without a reason. Only because she is obviously [Muslim/not a Muslim]. You could see it because of her clothes and appearance". Two heavily injured men are in critical conditions. Halle's mayor Bernd Wiegand speaks of a "terrible terrorist attack, which was obviously targeted against [people who are part of the Islam religious community/people who are not part of the Islam religious community]".

\section{Appendix B. Stimulus Material Study 2}

\section{Appendix B.1. News Article 1}

[Religion undisclosed perpetrator version/Muslim perpetrator version] Two people killed in gun-shooting at Bar in Berlin-assassin shot by the police. 
Berlin-Wednesday night, a young man opened fire in a well-known bar in Berlin and shot two people dead and injured eleven-two of them are currently still in critical conditions. The Berlin police explained that the perpetrator entered the "Elephant Bar" around 10:00 p.m. and started firing. The assassin, a 24-year-old man, was shot dead by a police officer. [More information about the identity of the offender has not yet been released/The perpetrator seems to be a devout Muslim: a Qur'an was found in his bag and he wore a necklace with a star and crescent pendant, which is a well-known symbol in Islam.] The "Elephant Bar" is a well-known bar in Kreuzberg, a district of Berlin that is especially known for its lively and diverse bar and restaurant scene. On Wednesday evening, the bar hosted its popular "Music and Culture Evening", organized once a month by the LGBT (Lesbian-Gay-Bisexual Transgender) community and bringing together many people from different cultures.

\section{Appendix B.2. News Article 2}

[Religion undisclosed perpetrator version/Muslim perpetrator version] Five people injured after knife attack in Karlsruhe-perpetrator arrested by the police.

On Tuesday, a 37-year-old man attacked the participants of a demonstration in Karlsruhe with a knife-five people were injured, two of them heavily. An eyewitness reported how the man suddenly took a "30 cm long" knife out of his jacket pocket. Then he began randomly attacking people participating in the "Pro Choice" demonstration. The man could be arrested by the police. [More detailed information on the perpetrator has not yet been announced by the police in Karlsruhe/More detailed information on the perpetrator of the police in Karlsruhe has not yet been announced, however, several eyewitnesses reported that the perpetrator is probably a devout Muslim: The man wore a Taqiyah, a skullcap, which Muslim men wear to prayer, and shouted "I did this for Allah!" during his arrest]. The demonstration, organized by the pro-choice movement, took place in front of the city hall in Karlsruhe and involved about 400 participants. Every year, activists meet to demonstrate women's self-empowerment and social exclusion after having an abortion. The demonstration takes place once a year in various cities throughout Germany.

\section{References}

Ahmed, Saifuddin, and Jörg Matthes. 2017. Media representation of Muslims and Islam from 2000 to 2015 : A meta-analysis. International Communication Gazette 79: 219-44. [CrossRef]

Arendt, Florian. 2015. Toward a dose-response account of media priming. Communication Research 42: 1089-115. [CrossRef]

Berman, Sheri. 2003. Islamism, revolution, and civil society. Perspectives on Politics 1: 258-72. [CrossRef]

Chuang, Angie, and Robin Chin Roemer. 2013. The immigrant Muslim American at the boundary of insider and outsider: Representations of Faisal Shahzad as "homegrown" terrorist. Journalism and Mass Communication Quarterly 90: 89-107. [CrossRef]

Das, Enny, Brad J. Bushman, Marieke D. Bezemer, Peter Kerkhof, and Ivar E. Vermeulen. 2009. How terrorism news reports increase prejudice against outgroups: A terror management account. Journal of Experimental Social Psychology 4: 453-59. [CrossRef]

Devine, Patricia G. 1989. Stereotypes and prejudice: Their automatic and controlled components. Journal of Personality and Social Psychology 56: 5-18. [CrossRef]

Dixon, Travis L. 2006. Schemas as average conceptions: Skin tone, television news exposure, and culpability judgments. Journalism and Mass Communication Quarterly 83: 131-49. [CrossRef]

Dixon, Travis L. 2007. Black Criminals and White Officers: The Effects of Racially Misrepresenting Law Breakers and Law Defenders on Television News. Media Psychology 10: 270-91. [CrossRef]

Dixon, Travis L., and Charlotte L. Williams. 2015. The Changing Misrepresentation of Race and Crime on Network and Cable News. Journal of Communication 65: 24-39. [CrossRef]

Eagly, Alice H., and Shelly Chaiken. 1993. The Psychology of Attitudes. Harcourt: Harcourt Brace Jovanovich College Publishers.

Eikmeier, Dale C. 2007. Qutbism: An ideology of islamic-fascism. Parameters 37: 85-97. 
Global Terrorism Index. 2017. Measuring and Understanding the Impact of Terrorism. Available online: https:/ / reliefweb.int/sites / reliefweb.int/files / resources / Global $\% 20$ Terrorism $\% 20$ Index $\% 202017 \% 20 \%$ 284\%29.pdf (accessed on 10 September 2018).

Higgins, E. Tory. 2000. Social cognition: Learning about what matters in the social world. European Journal of Social Psychology 30: 3-39. [CrossRef]

Hogg, Michael A., and Scott A. Reid. 2006. Social identity, self-categorization, and the communication of group norms. Communication Theory 16: 7-30. [CrossRef]

Hussain, Ali J. 2007. The media's role in a clash of misconceptions: The case of the Danish Muhammad cartoons. The Harvard International Journal of Press/Politics 12: 112-30. [CrossRef]

Ibrahim, Dina. 2010. The framing of Islam on network news following the September 11th attacks. International Communication Gazette 72: 111-25. [CrossRef]

Imai, Kosuke, Luke Keele, and Dustin Tingley. 2010. A general approach to causal mediation analysis. Psychological Methods 15: 309-34. [CrossRef] [PubMed]

Lee, Sherman A., Jeffrey A. Gibbons, John M. Thompson, and Hussam Timani. 2009. The Islamophobia scale: Instrument development and initial validation. The International Journal for the Psychology of Religion 19: 92-105. [CrossRef]

Livingston, Robert W. 2001. What you see is what you get: Systematic variability in perceptual-based social judgment. Personality and Social Psychology Bulletin 27: 1086-96. [CrossRef]

Mahony, Inez. 2010. Diverging frames: A comparison of Indonesian and Australian press portrayals of terrorism and Islamic groups in Indonesia. International Communication Gazette 72: 739-58. [CrossRef]

Major, Brenda, and Laurie T. O’Brien. 2005. The social psychology of stigma. Annual Review of Psychology 56: 393-421. [CrossRef] [PubMed]

Marsden, George M. 2006. Fundamentalism and American Culture. Oxford: Oxford University Press.

Mendelberg, Tali. 2001. The Race Card: Campaign Strategy, Implicit Messages, and the Norm of Equality. Princeton: University Press.

Moghaddam, Fathali M., and Anthony J. Marsella, eds. 2004. Understanding Terrorism: Psychological Roots, Consequences, and Interventions. Washington, DC: American Psychological Association.

Nacos, Brigitte L. 2016. Mass-Mediated Terrorism. Mainstream and Digital Media in Terrorism and Counterterrorism. Lanham: Rowman and Littlefield.

Park, Bernadette, and Myron Rothbart. 1982. Perception of out-group homogeneity and levels of social categorization: Memory for the subordinate attributes of in-group and out-group members. Journal of Personality and Social Psychology 42: 1051-68. [CrossRef]

Park, Jaihyun, Karla Felix, and Grace Lee. 2007. Implicit attitudes toward Arab-Muslims and the moderating effects of social information. Basic and Applied Social Psychology 29: 35-45. [CrossRef]

Piazza, James A. 2009. Is Islamist terrorism more dangerous? An empirical study of group ideology, organization, and goal structure. Terrorism and Political Violence 21: 62-88. [CrossRef]

Powell, Kimberly A. 2011. Framing Islam: An analysis of US media coverage of terrorism since 9/11. Communication Studies 62: 90-112. [CrossRef]

Powell, Kimberly A. 2018. Framing Islam/Creating Fear: An Analysis of US Media Coverage of Terrorism from 2011-2016. Religions 9: 257. [CrossRef]

Price, Vincent, and David Tewksbury. 1997. News values and public opinion: A theoretical account of media priming and framing. In Progress in Communication Sciences. New York: Ablex, pp. 173-212.

Ranganath, Kate A., and Brian A. Nosek. 2008. Implicit attitude generalization occurs immediately; explicit attitude generalization takes time. Psychological Science 19: 249-54. [CrossRef] [PubMed]

Rothgerber, Hank. 1997. External intergroup threat as an antecedent to perceptions of in-group and out-group homogeneity. Journal of Personality and Social Psychology 73: 1206-12. [CrossRef] [PubMed]

Saleem, Muniba, and Craig A. Anderson. 2013. Arabs as terrorists: Effects of stereotypes within violent contexts on attitudes, perceptions, and affect. Psychology of Violence 3: 84-99. [CrossRef]

Saleem, Muniba, Grace S. Yang, and Srividya Ramasubramanian. 2016. Reliance on Direct and Mediated Contact and Public Policies Supporting Out-group Harm. Journal of Communication 66: 604-24. [CrossRef]

Saleem, Muniba, Sarah Prot, Craig A. Anderson, and Anthony F. Lemieux. 2017. Exposure to Muslims in Media and Support for Public Policies Harming Muslims. Communication Research 44: 841-69. [CrossRef] 
Satti, Mohamed. 2015. Framing the IS on Al Jazeera English and the BBC websites. Journal of Arab and Muslim Media Research 8: 37-53. [CrossRef]

The Guardian. 2017. Anti-Muslim Hate Crimes Increase Fivefold since London Bridge Attacks. Available online: https://www.theguardian.com/uk-news/2017/jun/07/anti-muslim-hate-crimesincrease-fivefold-since-london-bridge-attacks (accessed on 10 September2018).

The Independent. 2017. Finsbury Park Mosque Attack: Man Shouted 'I'm Going to Kill All Muslims' after Suspected London Terror Attack. Available online: http://www.independent.co.uk/news/uk/homenews / finsbury-park-attack-latest-witnesses-man-shouted-kill-muslims-london-mosque-van-crash-deadpolice-a7796601.html (accessed on 10 September 2018).

Tingley, Dustin, Teppei Yamamoto, Kentaro Hirose, Luke Keele, and Kosuke Imai. 2014. Mediation: R package for causal mediation analysis. Journal of Statistical Software 59: 1-38. [CrossRef]

Turner, John C., Michael A. Hogg, Penelope J. Oakes, Stephen D. Reicher, and Margaret S. Wetherell. 1987. Rediscovering the Social Group: A Self-Categorization Theory. New York: Blackwell.

Valentino, Nicholas A., Vincent L. Hutchings, and Ismail K. White. 2002. Cues that matter: How political ads prime racial attitudes during campaigns. American Political Science Review 96: 75-90. [CrossRef]

Von Sikorski, Christian, Desirée Schmuck, Jörg Matthes, and Alice Binder. 2017. "Muslims are not Terrorists": Islamic State coverage, journalistic differentiation between terrorism and Islam, fear reactions, and attitudes toward Muslims. Mass Communication and Society 20: 825-48. [CrossRef]

Von Sikorski, Christian, Jörg Matthes, and Desirée Schmuck. 2018. The Islamic State in the News: Journalistic Differentiation of Islamist Terrorism from Islam, Terror News Proximity, and Islamophobic Attitudes. Communication Research. advance online publication. [CrossRef]

Wise, Amanda, and Jan Ali. 2008. Muslim Australians and Local Government: Grassroots Strategies to Improve Relations between Muslims and Non-Muslim Australians. Sydney: Centre for Research on Social Inclusion, Macquarie University, Available online: http:/ / hdl.handle.net/1959.14/324486 (accessed on 10 September 2018).

Woods, Joshua. 2007. What we talk about when we talk about terrorism: Elite press coverage of terrorism risk from 1997 to 2005. The Harvard International Journal of Press/Politics 12: 3-20. [CrossRef]

(C) 2018 by the authors. Licensee MDPI, Basel, Switzerland. This article is an open access article distributed under the terms and conditions of the Creative Commons Attribution (CC BY) license (http:/ / creativecommons.org/licenses/by/4.0/). 